Article

\title{
Typologies and Spatialization of Agricultural Production Systems in Rondônia, Brazil: Linking Land Use, Socioeconomics and Territorial Configuration
}

\author{
Cláudio Almeida ${ }^{1, *}$, Moisés Mourão Jr. ${ }^{2}$, Nadine Dessay ${ }^{3}$, Anne-Elisabeth Lacques ${ }^{3}$, \\ Antônio Monteiro ${ }^{1}$, Laurent Durieux ${ }^{3}$, Adriano Venturieri ${ }^{2}$ and Frédérique Seyler ${ }^{3}$ \\ 1 National Institute for Space Research-INPE 1, Av. dos Astronautas, 1758 CP. 515, \\ 12227-010 São José dos Campos, SP, Brazil; miguel@dpi.inpe.br \\ 2 Brazilian Agricultural Research Corporation-EMBRAPA Eastern Amazon, Trav. Dr. Enéas Pinheiro, s/n ${ }^{\circ}$, \\ Caixa postal 48, 66095-100 Belém, PA, Brazil; moises.mourao@embrapa.br (M.M.); \\ adriano.venturieri@embrapa.br (A.V.) \\ 3 Institut de Recherche pour le Développement-IRD UMR Espace-Dev, 500 rue Jean François Breton, \\ 340930 Montpellier, France; nadine.dessay@ird.fr (N.D.); anne-elisabeth.laques@ird.fr (A.-E.L.); \\ laurent.durieux@ird.fr (L.D.); frederique.seyler@ird.fr (F.S.) \\ * Correspondence: claudio.almeida@inpe.br; Tel.: +55-12-3208-6461
}

Academic Editor: Richard Aspinall

Received: 30 March 2016; Accepted: 13 June 2016; Published: 22 June 2016

\begin{abstract}
The current Amazon landscape consists of heterogeneous mosaics formed by interactions between the original forest and productive activities. Recognizing and quantifying the characteristics of these landscapes is essential for understanding agricultural production chains, assessing the impact of policies, and in planning future actions. Our main objective was to construct the regionalization of agricultural production for Rondônia State (Brazilian Amazon) at the municipal level. We adopted a decision tree approach, using land use maps derived from remote sensing data (PRODES and TerraClass) combined with socioeconomic data. The decision trees allowed us to allocate municipalities to one of five agricultural production systems: (i) coexistence of livestock production and intensive agriculture; (ii) semi-intensive beef and milk production; (iii) semi-intensive beef production; (iv) intensive beef and milk production, and; (v) intensive beef production. These production systems are, respectively, linked to mechanized agriculture (i), traditional cattle farming with low management, with (ii) or without (iii) a significant presence of dairy farming, and to more intensive livestock farming with (iv) or without (v) a significant presence of dairy farming. The municipalities and associated production systems were then characterized using a wide variety of quantitative metrics grouped into four dimensions: (i) agricultural production; (ii) economics; (iii) territorial configuration, and; (iv) social characteristics. We found that production systems linked to mechanized agriculture predominate in the south of the state, while intensive farming is mainly found in the center of the state. Semi-intensive livestock farming is mainly located close to the southwest frontier and in the north of the state, where human occupation of the territory is not fully consolidated. This distributional pattern reflects the origins of the agricultural production system of Rondônia. Moreover, the characterization of the production systems provides insights into the pattern of occupation of the Amazon and the socioeconomic consequences of continuing agricultural expansion.
\end{abstract}

Keywords: Amazon; land use; multidimensionality; socioeconomic; TerraClass 


\section{Introduction}

The colonization of the Brazilian Amazon has directly led to a new geography, with significant impacts on the natural environment and regional development [1,2]. The waves of settlement produced a strong integration of local livestock supply chains with national and international markets, further reinforcing and incentivizing the process of occupation [3-5]. However, the occupation of land has been characterized by different systems of production that generate different costs and benefits for the economy, socioecological systems and farming [6-9]. Such differences in production originate from different land use systems and/or the different techniques adopted for the same land use in different production systems.

An in-depth knowledge of regional geography is therefore fundamental to understand the spatial distribution and evolution of agricultural supply chains, in order to assess the impact of current policies and future actions [10]. Knowledge of the effects of shifting land use is equally important in the search for sustainable solutions for impacted rural communities [11,12], since themes such as climate change, food security, biodiversity and energy sources will also be strongly influenced by regional geographies [13].

Spatial analysis of socioeconomic data is an important element in the construction of rural development indices. Such indices lack robustness if they are based on an insufficient number of metrics/indicators and, ideally, should incorporate measures of land use and landscape characteristics [14]. More generally, the analysis of spatial patterns of socioeconomic indicators contributes to an understanding of the spatial variations of the territory [15].

Agronomic geography concerns the identification and analysis of spatial variation in agricultural practices, uncovering the many factors that contribute to this spatial distribution [16-18]. The formation of different agricultural production regions, within territorial dynamics linking geography and economics [18,19], highlights the importance of studying geographical development at a regional scale.

Previous studies analyze socioeconomic data from the demographic census and/or agricultural census in the context of land use changes in the Amazon $[20,21]$ or to explain poverty among agricultural producers in Brazil [22]. Others employ landscape analysis techniques to study land use changes [23]. In this paper, we explore how spatial analysis of land use and socioeconomics attributes can contribute to the discovery of patterns of distribution of agricultural system productions. Our hypothesis is that it is possible to identify the predominant systems of production in each municipality based on the percentage of annual crop, clean pasture, and dairy cows.

With the aim of contributing to geographical knowledge of agricultural production systems in Rondônia State, Brazil, the objectives of this article are to identify the predominant systems at a municipal scale, and to characterize these systems using a wide variety of quantitative metrics grouped into four dimensions: (i) agricultural production; (ii) economics; (iii) territorial configuration, and; (iv) social characteristics.

\section{Materials and Data Preparation}

\subsection{Study Area}

The Brazilian State of Rondônia covers $237,590 \mathrm{~km}^{2}$ and is currently divided into 52 municipalities. The state has its origins in the Guaporé territory (formed from parts of Amazonas and Mato Grosso States) that was created in 1943 (Federal Decree No. 5.912, 13 September 1943). In 1956, this territory was renamed Rondônia and was officially converted into a state in 1981 (Complementary Law No. 41, 22 December 1981). Significant colonization of Rondônia began in the early 20th century in response to the growth of latex extraction in the Amazon and facilitated by the construction of the Madeira-Mamore railway. The construction of the BR-364 highway in the 1970s linked the capital, Porto Velho, to the southcentral region of the state and integrated local supply chains with the regional and global market $[24,25]$. This process of occupation intensified throughout the century, reaching its peak in the 1980s [26,27]. 
During the 1970s and 1980s, the National Institute of Colonization and Agrarian Reform (INCRA), with the support of national and international banks and (national and international) funding agencies, facilitated the settlement of tens of thousands of families of migrants in Rondônia. The settlement served the dual purpose of supporting the Brazilian Government's Amazon occupation policy to relieve agrarian conflicts in other regions of Brazil, and also to facilitate the integration of the Amazon into Brazilian economic space $[10,26,28-30]$.

This intense process of agricultural colonization was mainly held by small farmers in settlement projects along the state's open road system [24,25]. Inevitably, this process led to profound changes in land cover, especially the conversion of native forest to agricultural land: Rondônia has experienced the third highest percentage reduction of original forest cover in the Brazilian Legal Amazon [31]. This process of configuration/reconfiguration of territory gave rise to regions that specialized in certain production chains, such as the establishment of a grain-producing region in the south of Rondônia [32]. Data from the TerraClass 2008 project confirm such specialization, demonstrating that in 2008 the deforested areas in Rondônia were mainly occupied by pastures $(79 \%)$, followed by secondary vegetation (16\%) and annual (crop-based) agriculture ( $2 \%$ ) concentrated in the south of the state [33].

\subsection{Metrics to Characterization of Production Systems}

In order to perform the regional analysis and further characterize the agricultural production systems, a variety of quantitative metrics (full specifications in Table A1 in Appendix A) were applied at the municipal level. To facilitate analysis and interpretation, these metrics were grouped into four dimensions; (i) agricultural production; (ii) economics; (iii) territorial configuration, and; (iv) social characteristics.

\subsubsection{Dimension 1: Agricultural Production}

We used data from the survey of municipal agricultural production, coordinated by the Brazilian Institute of Geography and Statistics (IBGE) [34] to evaluate agricultural production. Data was retrieved on production of beef and milk cattle, planted area of coffee, and income of the top five annual crops of the state (rice, beans, cassava, corn and soybeans). It should be noted that several other land uses (e.g., annual and perennial crops as well as the economic exploitation of other animals) occur in Rondônia. However, the contribution of cattle (beef and milk) and the above-listed crops represent more than $93 \%$ of total agricultural income in the state. For agricultural income, the sum of the value of agricultural production and livestock, available in the literature, was considered [35]. The selected agropastoral activities were present in all municipalities with the exception of soybean production. Although soybean is only grown in 12 out of 52 municipalities, it has a relatively high cultivated area and, where present, makes a significant contribution to the local economy [34,35].

To complement the original IBGE data [34], further metrics were calculated that indicate livestock productivity in relation to pasture area (derived from the TerraClass data) and the number of animals per municipality (data from IBGE). For crops, the financial income generated by each major crop to local agricultural economy was recorded [34], as was the percentage of area occupied by coffee in relation to the total production area of each municipality.

\subsubsection{Dimension 2: Economics}

\subsubsection{Gross Domestic Product (GDP)}

We used Gross Domestic Product (GDP) as a metric to study the impact and economic contribution of different land uses on the local economy. GDP is the sum of monetary values of all goods and services produced in a given region over a given period. It consists of the gross value added by agricultural activities (Agricultural GDP), the gross value added of industry (Industrial GDP), and gross value added by services (Services GDP).

Municipal GDP data for the years 2000 (T1) and 2010 (T2) were retrieved from the IBGE database [34]. GDP was divided into Agricultural GDP and total GDP for each municipality to 
allow calculation of the indirect contributions of the agricultural sector (e.g., sale of fuel, services, etc.). These indirect contributions are not included in the agricultural GDP, but they may be indirectly related to the agricultural production chain and contribute to total GDP.

GDP data is available in the form of an absolute monetary value for the entire municipality. Within each municipality, agricultural production only takes place in deforested areas (the minor exception being timber production or non-timber forest products). Thus, it may be possible to, at least partially, infer the production efficiency of different land use systems by generating new metrics that take into consideration the deforested area of each municipality (GDP per $\mathrm{km}^{2}$ deforested and Agricultural GDP per $\mathrm{km}^{2}$ deforested). We also estimated the GDP per capita for each municipality and the Agricultural GDP per capita for the rural zone.

\subsubsection{Agricultural Credit}

Brazil's Central Bank produces a statistical yearbook of rural credit which contains information on the number of operations and the resources available for rural credit operations for each Brazilian municipality [36]. Annual data from this dataset were used for the years 2000 to 2010. A statistical relationship was then sought between the amount of credit disbursed and the deforested area at the municipal scale. By dividing the total amount of rural credit in each year by the deforested area in each municipality for that year, we were able to calculate the average value (in R $\$$ ) of rural credit per $\mathrm{km}^{2}$ deforested.

\subsubsection{Logistics}

To study the relationship between agricultural production and transport infrastructure, data was obtained for the general road network for Rondonia from the Amazon Protection System-SIPAM [37]. We used this data to calculate a metric of municipal road density by dividing the total perimeter of roads in a municipality by the total area of that municipality. We adopted a similar approach to assess hydrographic network: data was retrieved from SIPAM [37] and municipal density of the network was calculated by dividing the total perimeter of the hydrographic network by the total area of the municipality.

\subsubsection{Dimension 3: Territorial Configuration}

Landscapes are the result of interactions between human societies and the space that surrounds them [38]. Landscape analysis is a way to study the intrinsic spatial heterogeneity within the natural environment [39], revealing territorial configurations. In this study, we apply metrics to allow the description of landscapes' configuration and composition [40]; such metrics have been commonly used to study deforestation and agricultural landscapes [41-44]. These metrics can also be used to identify and quantify spatial heterogeneity, providing a key link between patterns and processes [45]. Three types of territorial configuration data were analyzed: (i) deforested area [31]; (ii) land use distributions [33]; and (iii) environmental conservation units [46].

\subsubsection{The Amazon Deforestation Monitoring Project (PRODES)}

The Amazon Deforestation Monitoring Project (PRODES) [31] has been run by the Brazilian National Institute of Space Research (INPE) since 1988. The project produces annual maps of deforestation in the Brazilian Legal Amazon, and is able to identify deforested areas larger than 6.25 ha. We used these data in their original format of annual deforestation polygons. We also evaluated the full total area deforested, disregarding the date of occurrence.

\subsubsection{TerraClass}

Land use and land cover data are essential for understanding landscape configuration and for revealing the organizational strategies and patterns of agricultural production $[47,48]$. TerraClass data [33] with a spatial resolution of $30 \mathrm{~m}$ allows for both regional level and municipal level analysis 
of land use and land cover dynamics. TerraClass 2010 is available and contain the following classes: deforestation up to 2010; crop area (annual); unobserved area; urban area; mining; mosaic occupations; other areas; pasture with exposed soil; clean pasture; "dirty" pasture; regeneration with pasture; reforestation; and secondary vegetation. To study the spatial configuration of these data, the following landscape metrics were calculated: area/perimeter ratio, as an indicator of polygon shape; average area; density of polygons; and density of classes as indicators of landscape fragmentation.

\subsubsection{Conservation Units}

Information on all federal and state conservation units was retrieved from maps provided by the Brazilian Ministery of Environmental [46]. We recorded the percentage of the municipal area designated as a conservation unit.

\subsubsection{Dimension 4: Social Characteristics}

Socioeconomic development indices can be used as estimators of quality of life, and are relevant in the context of regional socioeconomic development analysis [49], although they should be applied with caution given their many limitations [50]. We used a Municipal Human Development Index (MHDI) and density of people living in poverty (data from the Atlas of Human Development in Brazil [51]) to assess whether the specialization in certain agricultural production systems was associated with social differences between groups of municipalities. We also retrieved data on the total number of inhabitants and the number of inhabitants in the rural zone for each municipality (data from a population estimates conducted by the IBGE [34]), and the areas of settlement projects within each municipality.

Although the MHDI is insufficient to fully capture the level of municipal human development, it does provide a synthetic view of some of the key development issues such as health, education and income [50]. A similar procedure was used for GDP and Agricultural Credit (see Sections 2.2.2.1. and 2.2.2.2.) which were used to create an index to represent the population from the deforested area within each municipality.

We also collected data of the boundaries of settlement projects for agrarian reform, aimed to account for the percentage on the municipality occupied by such projects. Polygons of the settlements were downloaded from the website of the National Institute of Colonization and Agrarian Reform (INCRA), a Brazilian federal agency responsible for agrarian reform and land consolidation [52].

Appendix A provides Table A1 with the assigned name of each metric (metric), a brief description, and the unit of measurement.

\section{Metrics and Data Analysis}

\subsection{Identification of Agricultural Production Systems}

Despite having major limitations, GDP is a key indicator of regional economic development [49]. To identify the predominant agricultural production system in each municipality, a metric was created to serve as an indicator of the economic efficiency of land use. This metric was derived from the hypothesis that Agricultural GDP 2010 divided by the deforested area 2010 in each municipality (metric PIBAgroPRD_T2 in Appendix A) can be used to support the identification of agricultural production systems, because different productions systems should result in different economical improvements.

In our initial analysis, we treated PIBAgroPRD_T2 as a dependent variable and, using the 2010 TerraClass data, we performed an exploratory analysis to identify key trends (following [15]). In this exploratory analysis, we perceived that the percentage of clean pasture, dirty pasture and annual agriculture were an important factor for the separation of the municipalities in groups. Using an expert approach, we empirically arbitrate the classification of municipalities based on the proportional area of this land use/land cover classes. The analysis indicated the existence of three main groups: (1) The first group was associated with annual crop activity; (2) The second group with the predominance of "clean pastures" - characteristic of intensive livestock farming; and (3) The third group was associated with "dirty pastures" — characteristic of semi-intensive livestock farming. The identification of metrics 
and their value in classifying these three main groups was optimized empirically using specialized literature, empirical knowledge and exploratory analysis of the database, applied in the construction of the decision tree, which was designed from a set of rules defined by the expertise of the authors and other researchers. Its construction was guided by the "rule-based" approach [53].

In Rondônia, as throughout the Brazilian Amazon, there is a clear predominance of cattle pasture for beef production [54-56]. There are also areas characterized by a predominance of small farms, where dairy farming has significant local importance [57-59]. Unfortunately, it is not possible to separate pastures for beef production from those used for milk production using only TerraClass data. However, IBGE publishes annual figures for the size of cattle herds and the number of cows milked for each municipality. These two datasets can be combined to create a new metric that quantifies the relationship between the number of cows milked and the size of the local herd (metric NVacReb_T2 in Appendix A). This metric allowed a new level of the decision tree to be added that was able to distinguish municipalities where dairy farming coexists with beef farming from those where dairy farming is rare or non-existent. Moreover, municipalities with dairy farming could be split between those under semi-intensive production systems and those with intensive production systems.

\subsection{Characterization of Agricultural Production Systems}

\subsubsection{Concentration of Annual Crops and Coffee}

Each production system uses different strategies that can be translated into greater or lesser specialization in production. These specializations lead to differences in the degree of concentration in the production of annual and/or perennial crops. Knowing the degree of this concentration thus strengthens the understanding of production systems.

We sought to identify the predominant annual crop by comparing the production value (in 2010; $\mathrm{R} \$$ ) of five main annual crops (rice, beans, cassava, corn and soybeans). These crops were chosen because they are the most commonly used annual crops in the state [35]. Using data on annual income (in 2010; R\$) for each crop from IBGE's municipal agricultural research database [34], we calculated the percentage share of the production value for each of the five crops, identifying the culture with the largest financial contribution in each municipality.

Degree of diversification of agricultural activity was calculated based on the percentage share of each crop. Municipalities were classified as "concentrated" where agricultural income was predominantly derived from a single crop. In such concentrated municipalities, the financial importance of the main crop $\left(C_{1}\right)$ accounted for over $67 \%$ of the total income generated by the five crops (e.g., the main crop generates more than twice the income of the remaining four crops). In 2010, the average percentage contribution of the first $\left(C_{1}\right)$ and second $\left(C_{2}\right)$ most important crop was $61 \%$ and $23 \%$, respectively, which together accounted for $84 \%$ of total income. Municipalities were classified as "conjugated" when the main culture contributed less than $67 \%$ of total crop income and the sum of the percentages of the first and second culture was greater than $84 \%$ (i.e., crop activity was concentrated in two main crops). The remaining municipalities were classified as "diffused," reflecting that crop income was fairly evenly distributed between three or more crops. This set of rules is summarized in Table 1 .

Table 1. Rules to classification degree of concentration crops.

\begin{tabular}{ccc}
\hline Rules & Class of Concentration & Number of Principal Crops \\
\hline$C_{1} \geqslant 67 \%$ & "concentrated" & one crop \\
$C_{1}<67 \%$ and $C_{1}+C_{2} \geqslant 84 \%$ & "conjugated" & two crops \\
$C_{1}+C_{2}<84 \%$ & "diffused" & three or more crops \\
\hline
\end{tabular}

Coffee has an historical importance in agricultural production in Rondônia, ever since occupation of the territory in the 1970s [26]. The importance of coffee was estimated as its percentage of land cover in each municipality, calculated as: planted area of coffee [34] divided by the total area occupied by agriculture [33] in each municipality. 


\subsubsection{Verification of Metrics}

We use analysis of variance (ANOVA) to identify differences between the profiles of agricultural production systems at the municipal level based on the metrics used to characterize the four dimensions of these systems (see Appendix A). The average values of these profiles were ordered in order to establish a possible hierarchy (significance level of $5 \%-\alpha=0.05$; LSD test).

\section{Results}

\subsection{Localization of Agricultural Production Systems}

We successfully identified various metrics and values to be used as separation criteria in the decision tree. The main criterion branch was based on the land cover of annual crops and livestock rearing. Municipalities with annual crop land cover values above or equal to $10 \%$ were classified as belonging to the crop agriculture domain; below this figure they were classified as belonging to the livestock domain. These two domains were then further subdivided.

In the crop agriculture domain, municipalities characterized by less than $30 \%$ "clean" pasture were classified as strictly linked to crop agriculture (Dominant Crop Agriculture-DCA). Municipalities where mechanized crop agriculture coexists with substantial pasture areas (where the percentage of "clean" pasture is equal to or greater than $30 \%$ ) were classified as coexistence zones between crop agriculture and the livestock domain (Coexistence Area-CA).

The livestock domain was subdivided based on presence of more than $60 \%$ of "clean" pasture. Municipalities meeting this criterion were characterized as intensive livestock farming. Municipalities with less than $60 \%$ of "clean" pasture were classified as semi-intensive livestock farming.

The presence of dairy farming was identified by the percentage of animals milked within the municipal flock. Municipalities with $10 \%$ or more milked animals were classified as having a significant presence of dairy farming: below this value they were classified as without a significant presence of dairy farming.

The above classification was applied to both the intensive and semi-intensive livestock systems to generate four groups; (i) intensive livestock farming without significant dairy farming (Intensive Beef-IB); (ii) intensive livestock farming with significant dairy farming (Intensive Beef Milk-IBM); (iii) semi-intensive livestock farming without significant dairy farming (Semi-Intensive Beef-SIB); and (iv) semi-intensive livestock farming with significant dairy farming (Semi-Intensive Beef Milk-SIBM). This decision tree is shown in Figure 1.

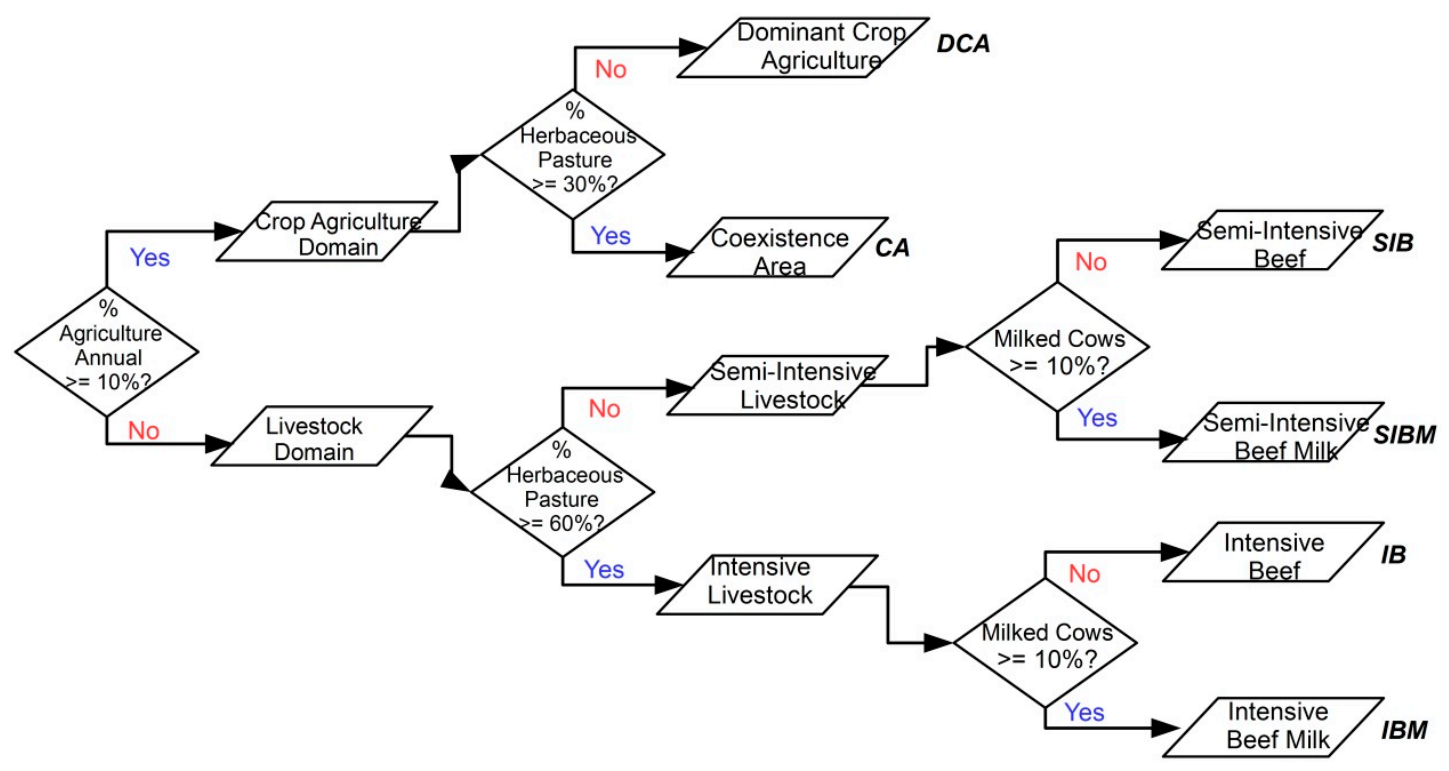

Figure 1. Decision tree to identify municipal agricultural systems in the State of Rondônia. 
All the municipalities of Rondônia were classified into agricultural production systems using the decision tree (Figure 2) except from the capital city, Porto Velho, which has unique socioeconomic characteristics that led us to create the special class name Capital.

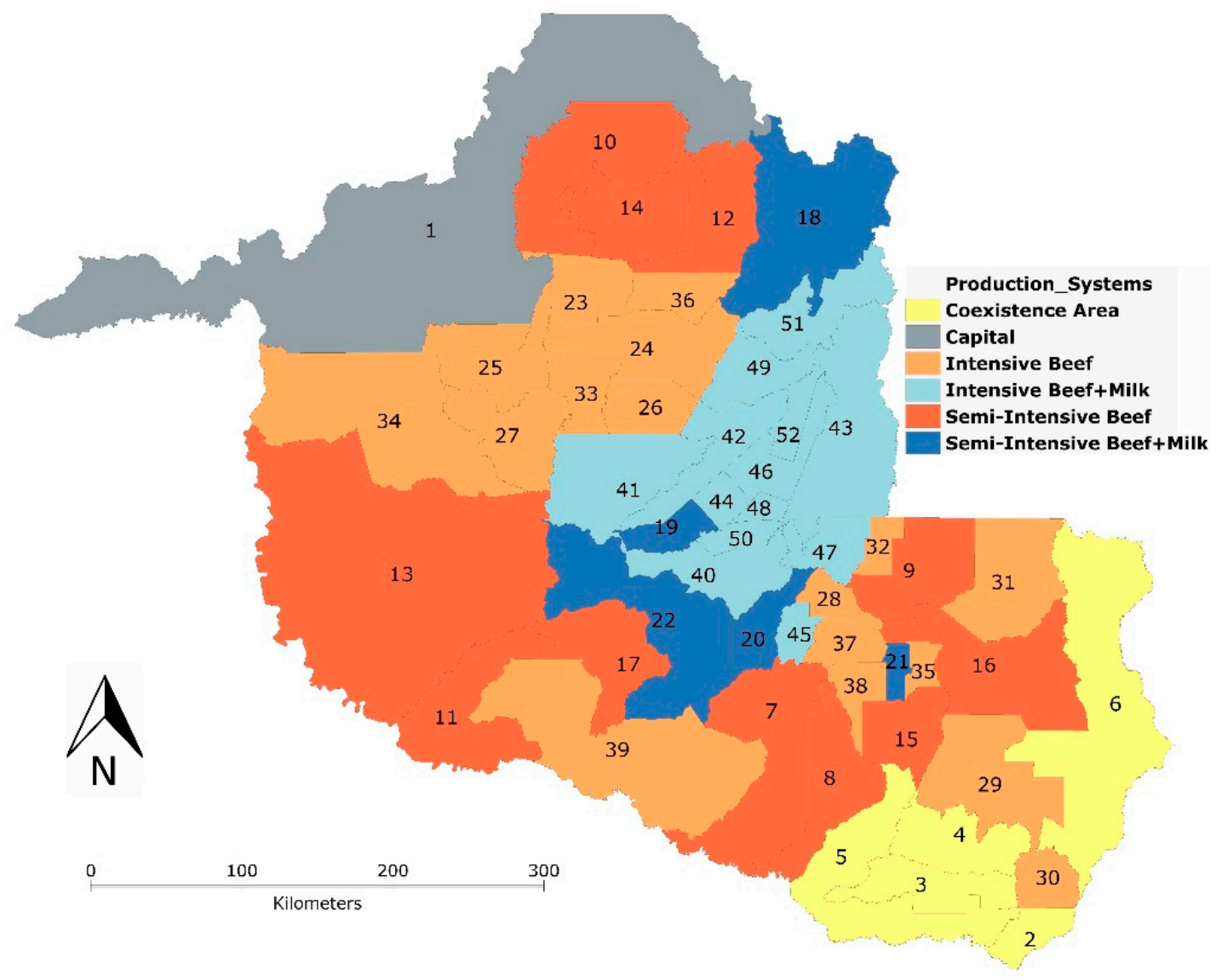

Figure 2. Distribution of agricultural production systems in Rondônia.

The numbers in Figures 2 and 3 represent the municipality name. The names of municipalities can be found in Table 2.

\subsection{Characterization of Agricultural Production Systems}

\subsubsection{Concentration of Annual Crops}

Following the methodology described in Section 3.2.1, the degree of concentration of the main five crops' production was identified (Table 2; Figure 3). In total, 18 municipalities were classified as "concentrated," 7 as "conjugated," and 26 as "diffused." "Concentrated" municipalities were mainly located near state boundaries, while soybean (7 municipalities) and corn (6 municipalities) were mainly in the south of the state of respectively, corroborating both the literature [60] and land use data from the TerraClass project [33]. Cassava predominated in all regions of the state, except for the south, and was the main crop in 32 municipalities. Table A2 in the appended material shows the proportional economic contribution of the five major crops for each municipality. 
Table 2. Concentration of the five major crops.

\begin{tabular}{|c|c|c|c|}
\hline $\begin{array}{l}\text { Production } \\
\text { System }\end{array}$ & Concentration & Principal Crop & Municipality \\
\hline CA & "concentrated" & Soybean & $\begin{array}{l}\text { Cabixi (2), Cerejeiras (3), Corumbiara (4), Pimenteiras do } \\
\text { Oeste (5), Vilhena (6) }\end{array}$ \\
\hline \multirow{7}{*}{ IB } & \multirow{2}{*}{ "conjugated" } & Cassava & Rio Crespo (36) \\
\hline & & Corn & Espigão D'Oeste (31) \\
\hline & "concentrated" & Cassava & $\begin{array}{l}\text { Alto Paraiso (23), Buritis (25), Cacaulândia (26), Nova } \\
\text { Mamoré (34) }\end{array}$ \\
\hline & \multirow{4}{*}{ "diffused" } & Rice & $\begin{array}{l}\text { Ariquemes (24), Primavera de Rondônia (35), São Francisco } \\
\text { do Guaporé (39) }\end{array}$ \\
\hline & & Cassava & $\begin{array}{l}\text { Campo Novo de Rondônia (27), Castanheiras (28), Ministro } \\
\text { Andreazza (32), Montenegro (33), Rolim de Moura (37) }\end{array}$ \\
\hline & & Corn & Santa Luzia D’Oeste (38) \\
\hline & & Soybean & Chupinguaia (29), Colorado do Oeste (30) \\
\hline \multirow{5}{*}{ IBM } & \multirow{2}{*}{ "conjugated" } & Rice & Presidente Medici (47) \\
\hline & & Corn & Vale do Paraiso (52) \\
\hline & "concentrated" & Cassava & Ji-Paraná (43), Ouro Preto do Oeste (46) \\
\hline & \multirow[t]{2}{*}{ "diffused" } & Cassava & $\begin{array}{l}\text { Alvorada D'Oeste (40), Gov.Jorge Teixeira (41), Jaru (42), } \\
\text { Nova União (44), Novo Horizonte do Oeste (45), } \\
\text { Teixeirópolis (48), Theobroma (49), Vale do Anari (51) }\end{array}$ \\
\hline & & Corn & Urupa (50) \\
\hline \multirow{4}{*}{ SIB } & "conjugated" & Cassava & Cacoal (9), Costa Marques (11) \\
\hline & "concentrated" & Cassava & $\begin{array}{l}\text { Candeias do Jamari (10), Cujubim (12), Guajara-Mirim (13), } \\
\text { Itapuã do Oeste (14), Pimenta Bueno (16), Seringueiras (17) }\end{array}$ \\
\hline & \multirow{2}{*}{ "diffused" } & Cassava & Parecis (15) \\
\hline & & Corn & Alta Floresta do Oeste (7), Alto Alegre do Parecis (8) \\
\hline \multirow{4}{*}{ SIBM } & "conjugated" & Rice & São Miguel do Guaporé (22) \\
\hline & "concentrated" & Cassava & Machadinho D'Oeste (18) \\
\hline & \multirow{2}{*}{ "diffused" } & Rice & São Felipe D'Oeste (21) \\
\hline & & Cassava & Mirante da Serra (19), Nova Brasilândia D'Oeste (20) \\
\hline
\end{tabular}

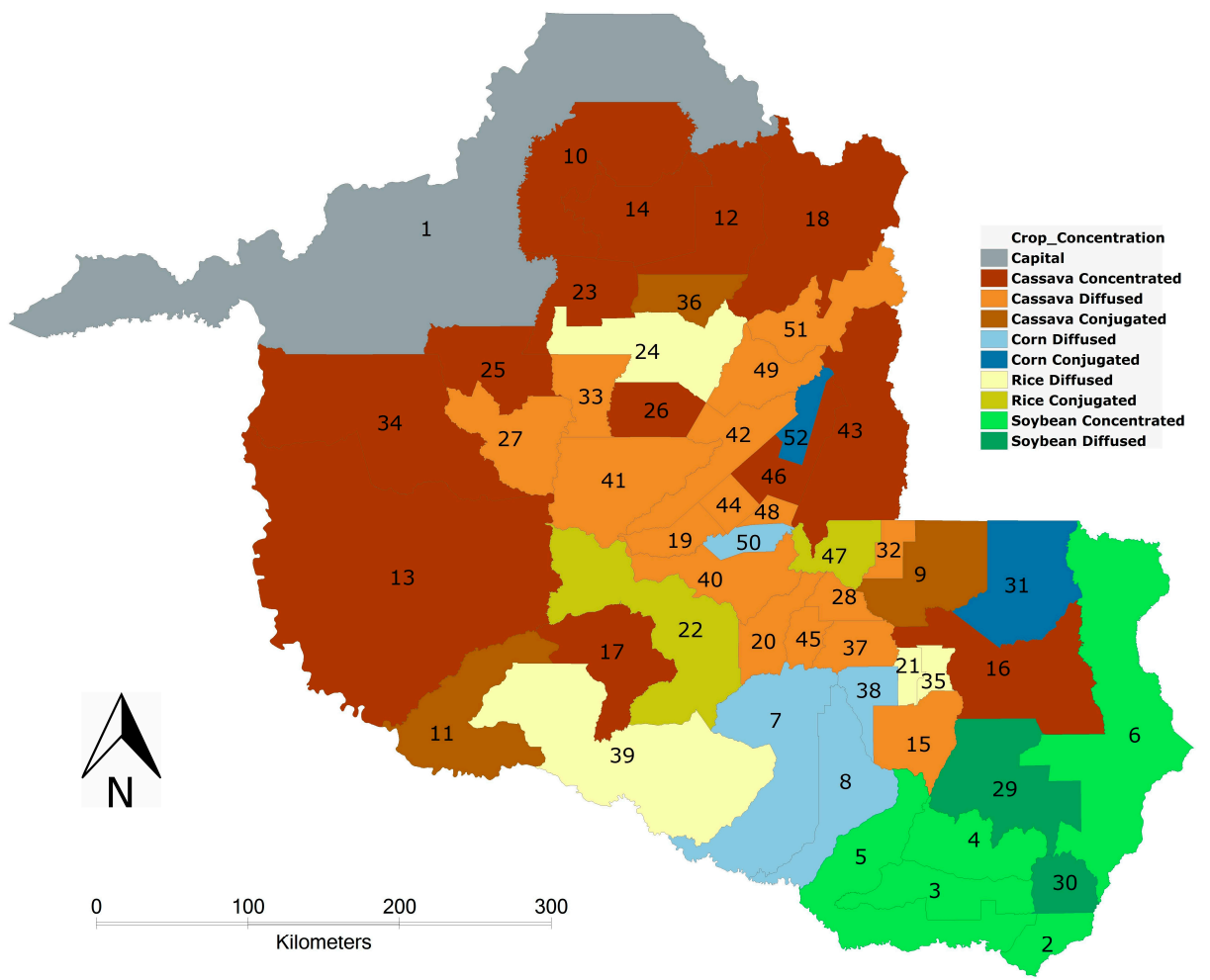

Figure 3. Localization and specialization of the five major crops in Rondônia (see text). 


\subsubsection{Quantitative Analysis of Production Systems}

The methodology applied in this study allowed evaluating the performance of 49 calculated metrics, distributed in four dimensions. This result showed how each production system impacted the territory studied in the agricultural production, economic, territorial configuration and social characteristics. Table 3 shows these results in seven columns. The first shows the dimension and data source according to definitions adopted in Section 2.2. The second column identifies the metric name. The three to seven columns show the mean value of the attributes in production systems CA, IB, IBM, SIB and SIBM. The differences between production systems are shown in ascending order of average values by use of letters, where groups marked with the same letter are not significantly different from each other. Metrics where no production system differed from any other were not marked with letters (see Section 3.2.2).

Table 3. Mean values and statistical significance of metrics of different agricultural production systems.

\begin{tabular}{|c|c|c|c|c|c|c|}
\hline \multirow[b]{2}{*}{ Dimension } & \multirow[b]{2}{*}{ Metric } & \multicolumn{5}{|c|}{ Agricultural Production System } \\
\hline & & CA & IB & IBM & SIB & SIBM \\
\hline \multirow{5}{*}{$\begin{array}{l}\text { agricultural production } \\
\text { (Section 2.2.1) }\end{array}$} & AMProp & $2.65(a)$ & $1.24(b)$ & 0.69 (b) & $1.45(\mathrm{ab})$ & $0.59(b)$ \\
\hline & NbovPast_T2 & $1.74(\mathrm{ab})$ & $2.05(\mathrm{ab})$ & $2.21(\mathrm{a})$ & $1.62(\mathrm{~b})$ & $1.91(\mathrm{ab})$ \\
\hline & NvacReb_T2 & $5.49(\mathrm{c})$ & $5.93(\mathrm{c})$ & 19.67 (a) & $4.87(\mathrm{c})$ & $15.18(b)$ \\
\hline & AMCafe_T2 & $50(\mathrm{c})$ & $2487(\mathrm{bc})$ & 3043 (abc) & $3346(\mathrm{ab})$ & 7376 (a) \\
\hline & DACafe_T2 & 0.04 & 0.11 & 2.21 & 2.66 & 2.27 \\
\hline \multirow{12}{*}{$\begin{array}{l}\text { economics (Section 2.2.2) } \\
\text { PIB (Sections 2.2.2.1.) }\end{array}$} & PIB_T2 & $414,322.20$ & $343,418.94$ & $329,017.15$ & $267,644.00$ & $196,971.80$ \\
\hline & PIBAgro_T2 & $98,103.80$ & $87,592.06$ & $72,330.62$ & $80,524.00$ & $75,123.80$ \\
\hline & EvPIB_T1T2 & $292,951.80$ & $246,097.56$ & $222,601.00$ & $211,807.58$ & $145,211.20$ \\
\hline & EvPIBAgro_T1T2 & $72,661.80$ & $67,386.13$ & $49,017.15$ & $68,555.92$ & $59,915.20$ \\
\hline & PIBPRD_T2 & 286.55 & 184.94 & 195.06 & 160.52 & 201.73 \\
\hline & EvPIBPRD_T1T2 & 181.39 & 121.63 & 125.18 & 111.32 & 142.16 \\
\hline & PIBAgroPRD_T2 & 73.90 & 53.54 & 56.13 & 47.08 & 81.36 \\
\hline & EvPIBAgroPRD_T1T2 & 49.86 & 37.67 & 36.25 & 36.33 & 64.37 \\
\hline & PIBHab_T2 & $22.21(\mathrm{a})$ & $15.04(\mathrm{ab})$ & $12.26(b)$ & $13.95(\mathrm{ab})$ & $14.68(\mathrm{ab})$ \\
\hline & EvPIBHab_T1T2 & 16.71 & 10.95 & 8.61 & 10.26 & 11.27 \\
\hline & PIBAgroPopR_T2 & 34.54 (a) & $12.66(b)$ & $8.44(b)$ & $13.64(b)$ & $9.56(b)$ \\
\hline & EvPIBAgroPopR_T1T2 & 26.51 (a) & $10.09(b)$ & $6.45(b)$ & $11.56(b)$ & 8.09 (b) \\
\hline \multirow{5}{*}{$\begin{array}{l}\text { economics (Section 2.2.2) } \\
\text { agricultural credit } \\
\text { (Section 2.2.2.2.) }\end{array}$} & NcrAg_T2 & 397.80 & 453.65 & 474.00 & 458.00 & 667.20 \\
\hline & NTCrAg_T1T2 & 4522.00 & 4582.00 & 6675.92 & 5673.55 & 8361.40 \\
\hline & RsMCrAg_T2 & $56.13(a)$ & $30.79(a b)$ & $29.45(a b)$ & $31.23(\mathrm{ab})$ & $12.56(b)$ \\
\hline & RsCrAgPRD_T2 & 15.35 (a) & $7.38(b)$ & $10.23(a b)$ & $6.19(\mathrm{~b})$ & $8.36(\mathrm{a})$ \\
\hline & RsMCrAgPRD_T1T2 & $8.95(a b)$ & $4.11(\mathrm{ab})$ & $4.58(\mathrm{ab})$ & $3.10(b)$ & 10.05 (a) \\
\hline \multirow{2}{*}{$\begin{array}{c}\text { economics (Section 2.2.2) } \\
\text { logístics (Section 2.2.2.3.) }\end{array}$} & DEst & 7.95 & 6.97 & 6.76 & 15.36 & 8.59 \\
\hline & DHdr & 0.058 & 0.047 & 0.061 & 0.062 & 0.066 \\
\hline \multirow{5}{*}{$\begin{array}{l}\text { territorial configuration } \\
\text { (Section 2.2.3) } \\
\text { PRODES (Section 2.2.3.1.) }\end{array}$} & AMPRD_T1T2 $\left(\mathrm{km}^{2}\right)$ & $0.220(\mathrm{a})$ & $0.183(b)$ & $0.140(\mathrm{c})$ & $0.179(b)$ & $0.150(\mathrm{c})$ \\
\hline & APPRD_T1T2 & $62.02(a)$ & $60.36(b)$ & $52.81(\mathrm{e})$ & $59.41(\mathrm{c})$ & $55.94(d)$ \\
\hline & DDesf_T-T2 (\%) & $41.5(\mathrm{~b})$ & $66.7(\mathrm{a})$ & $71.4(\mathrm{a})$ & $32.4(\mathrm{~b})$ & $54.4(\mathrm{ab})$ \\
\hline & DDesf_T1T2 (\%) & 4.9 & 10.4 & 6.3 & 11.6 & 8.3 \\
\hline & TxMDesf_T1aT2 (\%) & $1.4(b)$ & 3.0 (a) & 3.4 (a) & $2.0(\mathrm{ab})$ & $2.3(\mathrm{ab})$ \\
\hline \multirow{9}{*}{$\begin{array}{l}\text { territorial configuration } \\
\quad \text { (Section 2.2.3) } \\
\text { TerraClass (Section 2.2.3.2.) }\end{array}$} & AMPTC_T2 $\left(\mathrm{km}^{2}\right)$ & 0.712 & 0.651 & 0.413 & 0.418 & 0.360 \\
\hline & APTC_T2 & 44.67 (a) & 42.53 (c) & $38.26(\mathrm{e})$ & $43.42(b)$ & $40.94(d)$ \\
\hline & DPTC_T2 & $1.94(b)$ & $3.17(\mathrm{ab})$ & 3.40 (a) & $2.07(\mathrm{ab})$ & $3.18(a b)$ \\
\hline & DATCAA_T2 & 24.12 (a) & $1.19(b)$ & $0.07(b)$ & $0.72(b)$ & $0.52(b)$ \\
\hline & DATCMO_T2 & $0.22(b)$ & $1.43(\mathrm{~b})$ & $2.33(\mathrm{ab})$ & $1.58(b)$ & $6.23(\mathrm{a})$ \\
\hline & DATCPL_T2 & 45.07 (c) & $68.79(a)$ & $73.52(a)$ & $52.90(\mathrm{bc})$ & $56.10(b)$ \\
\hline & DATCPS_T2 & $6.07(b)$ & $7.16(b)$ & $5.55(b)$ & $13.32(a)$ & $11.42(a b)$ \\
\hline & DATCRP_T2 & 8.47 (a) & $3.01(b)$ & $2.25(b)$ & $9.01(\mathrm{a})$ & $7.30(\mathrm{a})$ \\
\hline & DATCVS_T2 & 13.90 & 16.37 & 15.79 & 19.44 & 17.72 \\
\hline $\begin{array}{l}\text { territorial configuration } \\
\text { (Section } 2.2 .3 \text { ) } \\
\text { conservation units (Section } \\
\text { 2.2.3.3.) } \\
\end{array}$ & DAUPA (\%) & $29.1(a b)$ & $12.2(b)$ & $16.5(b)$ & 43.9 (a) & $27.9(\mathrm{ab})$ \\
\hline \multirow{10}{*}{$\begin{array}{l}\text { social characteristics } \\
\text { (Section 2.2.4) }\end{array}$} & IDHM_T2 & 0.67 & 0.65 & 0.64 & 0.63 & 0.64 \\
\hline & IDHM_T1aT2 & 0.16 & 0.17 & 0.18 & 0.16 & 0.18 \\
\hline & DPobre_T2 & 16.76 & 19.87 & 23.33 & 23.13 & 26.52 \\
\hline & EvDPobre_T1T2 & -17.85 & -15.89 & -15.83 & -16.45 & -13.32 \\
\hline & DPAss & 0.20 & 0.47 & 0.52 & 0.20 & 0.28 \\
\hline & PopR_T2 & $3486.00(b)$ & $7387.81(\mathrm{ab})$ & $8449.85(\mathrm{ab})$ & $6695.25(\mathrm{ab})$ & 9964.40 (a) \\
\hline & EvPopR_T1T2 & -657.80 & -1141.31 & -2959.54 & 408.42 & -684.60 \\
\hline & PopRPRD_T2 & $2.62(\mathrm{c})$ & $4.81(b)$ & 6.97 (a) & $4.24(\mathrm{~b})$ & $8.08(\mathrm{a})$ \\
\hline & EvPopRPRD_T1T2 & $-0.99(\mathrm{a})$ & $-2.05(\mathrm{ab})$ & $-3.36(\mathrm{bc})$ & $-1.83(\mathrm{a})$ & $-3.59(\mathrm{c})$ \\
\hline & EvPopRPRD_T1T2 (\%) & -24.31 & -27.37 & -32.48 & -26.07 & -29.06 \\
\hline
\end{tabular}




\section{Discussion}

In this section, we discuss the differences between production systems in the context of the four analyzed dimensions.

\subsection{Agricultural Production}

For areas of coexistence between livestock production and intensive agriculture (CA), the predominant crop was soybean (Figure 4). In contrast, in all other production system-based livestock farming (SIBM, IB, SIB, IBM), cassava was the most important annual crop (Figure 4), thus reflecting its importance as a subsistence crop and its role in providing a supplementary income [57,61].

As with cassava, coffee cultivation predominated in cattle-based production systems (Figure 4), and only $0.04 \%$ of the area of municipalities was dominated by coexistence agriculture (CA). The area occupied by coffee was slightly higher in production systems that involve a substantial element of milk production (IBM and SIBM), perhaps indicating a greater compatibility in the production of these basic agricultural products.

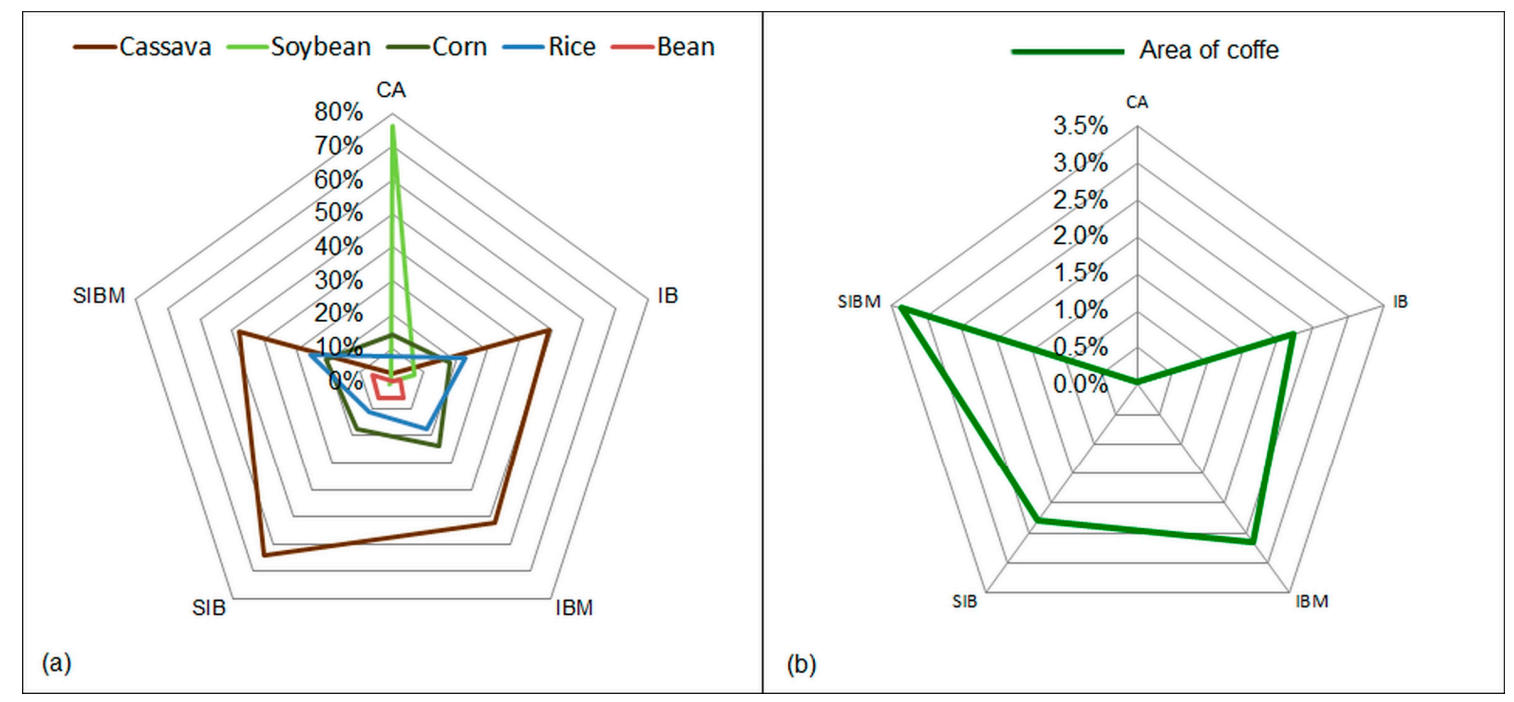

Figure 4. (a) Mean percentage of income generated from each major crop within each production system; (b) Mean percentage of area occupied by coffee in each production system.

The average size of the properties (AMProp) was higher for the CA Production System. This is in line with expectations, as grain crops require investment in larger tracts to increase profitability [62]. The SIB system had the second highest average area of property, probably because traditional livestock farming is characterized by low stocking densities which require extensive areas [63]. Moreover, smallholders use milk production to supplement their income [59]. The number of animals per grazing unit (NbovPast_T2) and the percentage of cows milked (NvacReb_T2) are also consistent with values reported in the literature, showing that municipalities with a predominance of "clean pastures" and dairy farming contribute to the increase in stocking. Indeed, stocking rates are higher than the national average and compatible with evolved technological systems [64,65].

\subsection{Economics}

GDP measures the economic value of agricultural, industrial and service activities [66]. Although the literature indicates that there is a relationship between GDP derived from agricultural activities and local development $[19,67,68]$, we found no significant differences in average values of economic metrics for municipalities with different production systems, except for Agricultural GDP per capita for rural areas (PIBAgroPopR_T2) and changes in this metric between 2000 and 
2010 (EvPIBAgroPopR_T1T2). In both metrics, the CA production system presented significantly higher values. This result supports the analysis of Le Tourneau [69], who demonstrated that highly mechanized production systems tend to have low population density, leading to higher values of GDP per capita.

Large variation in the absolute values of economic metrics linked to the GDP, may be associated with large variation in municipal land area and the size of the municipal population. Another problem is the estimate limitations of agricultural GDP, which may cause underestimates among sectors such as the subsistence economy in rural areas and the informal sector [49]. Regardless of consequences, this high variability contributed to the lack of statistical correlations related to metrics of GDP.

Average value per transaction of agricultural credit (RsMCrAg_T2) was highest in the CA production system, probably due to the high proportion of cultivated areas and the increased use of technology (e.g., seed and agricultural inputs with high cost production). The SIBM production system had the lowest value of RsMCrAg_T2, indicating that producers of this system when accessing the official agricultural credit, get smaller amounts of resources.

The amount of agricultural credit applied per $\mathrm{km}^{2}$ deforested (RsCrAgPRD_T2) was also higher in the CA production system. For livestock systems, there was a difference between systems with and without a significant presence of dairy farming, with higher credit for those with dairy farming, and slightly higher values for intensive systems compared to semi-intensive systems.

Regarding the logistics segment, where we try to infer the degree of accessibility in the predominant production systems, no significant difference has been reported. Part of this result can be attributed to the heterogeneity of the surface extension of the municipalities. Perhaps a new form of consideration in the classification of the "order" of the access segment (rivers and roads), as well as the separate assessment of conservation areas can offer better results.

\subsection{Territorial Configuration}

Previous studies using deforestation data have demonstrated increased intensification of land use near established agricultural frontiers [70-72], as indicated by increases in local infrastructure and the price of land, or the lack of new areas to deforest. We found higher values for the percentage of deforested area in 2010 (DDesf_T2) for the IB and IBM production systems. These systems have the highest percentage of clean pasture, corroborating that a more intensive use of pasture is mainly associated with the lack of new areas for expansion [72]. While production systems SIBM, SIB and CA have the lowest deforestation values, the SIB system has higher levels of "dirty pasture", i.e., "regenerating pasture" that are indicative of instability to the agricultural frontier. Unlike in IB or IBM land use systems, municipalities with the SIB system also tend to have significant portions of their territory within protected areas (as indicated by the DAPUC metric) that are not subject to legal deforestation. The low value of DDesf_T2 in municipalities with the CA system, where annual crops are of great importance, may be a consequence of the conversion of low quality pastures for grain production systems. However, more data on temporal patterns of land use and land cover are needed to confirm this hypothesis.

In the Amazonian context, variations of the average rate of deforestation between 2000 and 2010 (TxMDesf_T1aT2) are small, and are concentrated in the beginning of the period. Rates were below 1\% for all systems between 2009 and 2010, indicating a likely stabilization of deforestation in Rondônia State, since the current control and supervision policies are maintained. There was a higher average rate of deforestation for production systems linked to livestock compared to those linked to crop agriculture. This result supports the argument that intensification of land use has mainly occurred in well-established frontier areas. The change in deforested percentages between 2000 and 2010 (Ddesf_T1aT2) did not differ between production systems, although systems more closely associated with beef cattle had slightly higher values. 
There was a lower proportion of protected areas (DAPUC) in municipalities with the IB and IBM production systems, thereby strengthening the association between these systems and the proportion of deforested areas (see above).

The average area in relation to the area/perimeter of "PRODES" polygons (comprising the annual polygons including deforestation before 2000) did not differ within the five production systems. This can be explained by the large aggregation of PRODES data before 2000. Deforestation data were aggregated into a single class containing all (deforested) polygons detected between 1988 and 1997. This aggregation added many polygons and misrepresented the results of the landscape analysis.

When only the polygons of the period from 2000 to 2010 were analyzed, the average area of deforested polygons (AMPRD_T1aT2) was lower in production systems with significant milk production. This result is in accordance with the claim that milk production occurs mainly in small properties that produce small clearings. In contrast, municipalities with the CA production system contain larger polygons, and systems linked to meat production show intermediate values. The value of the ratio area/perimeter of deforested polygons between 2000 and 2010 (APPRD_T1T2) was different in all production systems, following the same trend as for average size of polygons: average value was highest for municipalities with the CA system, followed by systems linked to the production of meat and, finally, systems related to the production of milk.

The average size of TerraClass 2010 polygons (AMPTC_T2) showed no statistical differences between production systems. The mean area/perimeter of TerraClass polygons 2000 to 2010 (APTC_T1T2) showed statistical differences between all systems, with higher values for the CA system, intermediate values for beef-associated systems, and the lowest values for milk-associated systems. These trends follow those for the PRODES data and are consistent with expectations: the polygons in municipalities with the CA system are more regular, presumably due to the high level of mechanization in this production system. Municipalities with milk-associated production systems had lower values, indicating more irregularly shaped polygons associated with a greater reliance on manual labor.

\subsection{Social Characteristics}

The metrics associated with the human development index (HDI) and density of people living in poverty showed no statistically significant differences between municipalities with different production systems, neither for the 2010 data, $\mathrm{n}$ for the evolution of the HDI between 2000 and 2010. Although quality of life may be associated with agricultural income [67], production systems alone did not seem to strongly influence development metrics.

The rural populations in 2010 (T2) were lower in municipalities with the CA production system, indicating a low level of manpower in areas with a predominance of mechanized agriculture. Conversely, municipalities with milk-associated systems had higher rural populations because of their greater need for manual labor. All production systems showed a decrease in rural population (ranging from $-24.31 \%$ to $-32.48 \%$ ) in relation to the deforested area between 2000 and 2010 (PopRPRD_T1aT2), thereby indicating a displacement of the rural population during this period even as deforestation and agricultural production increased. Other factors may have contributed to this displacement of the rural population, such as the installation of enormous hydroelectric plants of Jirau and Santo Antonio. Such mega-projects significantly impacted migration and work availability in the region [73,74]. These results are in agreement with results of other studies in the State of Rondônia [7,75].

\section{Conclusions}

Deforested areas in Rondônia have been converted into a variety of agricultural uses. Using a combination of land use and socioeconomic data, we were able to identify five main production systems associated with mechanized agriculture (CA), livestock farming in semi-intensive (SIB and SIBM) or intensive (IB and IBM) regimes, with or without the presence of dairy farming. 
Production systems linked to mechanized agriculture and clean pastures were predominantly found in the consolidated region of the agricultural frontier, while pasture-based systems with "dirty pasture" tended to be located in regions of recent agricultural expansion. Moreover, production systems linked to milk production had a higher rural population. The methodology we adopted, using municipal administrative boundaries as a unit of analysis, was not sufficiently sensitive to detect significant differences in GDP generated by the different production systems. All production systems linked to livestock had stocking rates similar to or better than the national averages. Our landscape analysis indicated that the relationship area/perimeter of PRODES and TerraClass data varied significantly, with higher values in regions with predominantly mechanized agriculture and lower values for regions characterized by beef farming and, especially, milk production. This pattern was also reflected in a gradation in the shape of area polygons, with simpler, more regular forms associated with the CA system and more complex, irregular forms associated with the IBM and SIBM systems.

The results in the dimension territorial configuration were promising, even at the scale of sociopolitical units of municipalities. From these results, the possibility of a landscape analysis with a more detailed level, performed by using cell arrays, is inferred.

The results of this study can serve as a valuable baseline for future studies that utilize predictive models to assess the impact of expansion or contraction of certain production systems. By assessing the consequences of different plausible scenarios of agricultural development, such studies have the potential to provide a robust system for the evaluation of public policies.

Acknowledgments: The authors wish to thank the Coordination for the Improvement of Higher Level Personnel (Capes), for providing scholarships process BEX 6083/13-3, and the Institute of Research for Development through the unit ESPACE_DEV by host of the Ph.D. project of the first author. To Renne Poccard-Chapuis for the constructive comments and suggestions on the manuscript.

Author Contributions: Cláudio Almeida and Moisés Mourão Jr. engaged in case selection, data collection and analysis. The other authors made contributions to the search for relevant case studies; all authors contributed to preparation of the manuscript.

Conflicts of Interest: The authors declare no conflict of interest.

\section{Abbreviations}

The following abbreviations are used in this manuscript:

$\begin{array}{ll}\text { EMBRAPA } & \begin{array}{l}\text { Brazilian Agricultural Research Corporation-Empresa Brasileira de Pesquisa } \\ \text { Agropecuária (in Portuguese) }\end{array} \\ \text { GDP } & \text { Gross Domestic Product-Produto Interno Bruto } \\ \text { IBGE } & \begin{array}{l}\text { Brazilian Institute of Geography and Statistics-Instituto Brasileiro de Geografia } \\ \text { e Estatística }\end{array} \\ \text { INCRA } & \text { National Institute of Colonization and Agrarian ReformInstituto Nacional de } \\ \text { Colonização e Reforma Agrária } & \\ \text { MHE } & \text { Nacional Institute for Space research-Instituto Nacional de Pesquisas Espaciais } \\ \text { PRODES } & \text { Municipal Human Development Index-Indice de Desenvolvimento Humano Municipal } \\ \text { (in portuguese) } & \\ \text { SIPAM } & \text { Project for the Monitoring of Brasilian Amazon Forest by satellite-Projeto de } \\ \text { TerraClass } & \text { Monitoramento da Floresta Amazônica Brasileira por Satelite } \\ & \text { Amazon Protection System-Sistema de proteção da Amazônia } \\ & \text { Project for Monitoring the Land Use Land Cover in Brazilian Amazon-Projeto de } \\ & \text { Monitoramento do Uso e Cobertura da terra na Amazônica Brasileira }\end{array}$

\section{Appendix A}

\section{Metrics}

Table A1 provides the names of the variables analyzed, organized by dimension, and gives a small description of each metric and its respective measurement unit. 
Table A1. Metrics adopted and units of measurement.

\begin{tabular}{|c|c|c|c|}
\hline Dimension & Metric & Description & Unit \\
\hline \multirow{5}{*}{$\begin{array}{l}\text { agricultural production } \\
\text { (Section 2.2.1) }\end{array}$} & AMProp & $\begin{array}{l}\text { Mean area of properties within municipality (total area } \\
\text { of properties/total number of properties) }\end{array}$ & $\mathrm{km}^{2}$ \\
\hline & NbovPast_T2 & $\begin{array}{l}\text { Average capacity of TerraClass (Clean, dirty and } \\
\text { regenerating) pastures = Total number of cattle in } \\
\text { municipality 2010/Total number of TerraClass pastures } \\
\text { in } 2010\end{array}$ & Cattle/ha \\
\hline & NVacReb_T2 & $\begin{array}{l}\text { Proportion of milk cows within the total cattle } \\
\text { population }\end{array}$ & $\%$ \\
\hline & AMCafe_T2 & $\begin{array}{l}\text { Mean cultivation area of coffee in the municipality } \\
\text { in } 2010\end{array}$ & ha \\
\hline & DACafeT2 & $\begin{array}{l}\text { Percent of deforested area in each municipality } \\
\text { cultivated by coffee in } 2010\end{array}$ & $\%$ \\
\hline \multirow{12}{*}{$\begin{array}{l}\text { economics (Section 2.2.2) } \\
\text { PIB (Section 2.2.2.1.) }\end{array}$} & PIB_T2 & Municipal GDP in 2010 & $\mathrm{R} \$ \times 1000$ \\
\hline & PIBAgro_T2 & Municipal GDP for agricultural sector in 2010 & $\mathrm{R} \$ \times 1000$ \\
\hline & EvPIB_T1T2 & Evolution of GDP (2000 to 2010) = GDP $2010-$ GDP 2000 & $\mathrm{R} \$ \times 1000$ \\
\hline & EvPIBAgro_T1T2 & $\begin{array}{l}\text { Evolution of agricultural GDP }(2000 \text { to } 2010)= \\
\text { agricultural GDP } 2010 \text { - agricultural GDP } 2000\end{array}$ & $\mathrm{R} \$ \times 1000$ \\
\hline & PIBPRD_T2 & $\begin{array}{l}\text { Relationship between GDP in } 2010 \text { and mean } \\
\text { deforestation from PRODES in } 2010\end{array}$ & $\mathrm{R} \$ \times 1000 / \mathrm{km}^{2}$ PRODES \\
\hline & EvPIBPRD_T1T2 & $\begin{array}{l}\text { Evolution of PIBPRD between } 2000 \text { and } 2010= \\
\text { PIBPRD_T2 - PIBPRD_T1 }\end{array}$ & $\mathrm{R} \$ \times 1000 / \mathrm{km}^{2} \mathrm{PRODES}$ \\
\hline & PIBAgroPRD_T2 & $\begin{array}{l}\text { Relationship between agricultural GDP in } 2010 \text { de } 2010 \\
\text { and mean deforestation from PRODES in } 2010\end{array}$ & $\mathrm{R} \$ \times 1000 / \mathrm{km}^{2}$ PRODES \\
\hline & EvPIBAgroPRD_T1T2 & $\begin{array}{l}\text { Evolution of PIBAgroPRD between } 2000 \text { and 2010. = } \\
\text { PIBAgroPRD_T2 - PIBAgroPRD_T1 }\end{array}$ & $\mathrm{R} \$ \times 1000 / \mathrm{km}^{2}$ PRODES \\
\hline & PIBHab_T2 & $\begin{array}{l}\text { Relationship between GDP } 2010 \text { and human population } \\
\text { of municipality }\end{array}$ & $\mathrm{R} \$ \times 1000 /$ hab \\
\hline & EvPIBHab_T1T2 & $\begin{array}{l}\text { Evolution of the relationship between GDP and human } \\
\text { population of municipality 2000-2010 }\end{array}$ & $\mathrm{R} \$ \times 1000 /$ hab \\
\hline & PIBAgroPopR_T2 & $\begin{array}{l}\text { Relationship between GDP and human population of } \\
\text { the rural zone of the municipality in } 2010\end{array}$ & $\mathrm{R} \$ \times 1000 / \mathrm{hab}$ \\
\hline & EvPIBAgroPopR_T1T2 & $\begin{array}{l}\text { Evolution of the relationship between GDP and human } \\
\text { population of the rural zone of the municipality } \\
2000-2010\end{array}$ & $\mathrm{R} \$ \times 1000 /$ hab \\
\hline \multirow{5}{*}{$\begin{array}{l}\text { economics (Section 2.2.2) } \\
\text { agricultural credit } \\
\text { (Section } 2.2 .2 .2 .)\end{array}$} & NcrAg_2010 & $\begin{array}{l}\text { Mean number of agricultural credit operations in } \\
\text { municipality in } 2010\end{array}$ & Unit \\
\hline & NTCrAg_T1T2 & $\begin{array}{l}\text { Mean number of agricultural credit operations in } \\
\text { municipality 2000-2010 }\end{array}$ & Unit \\
\hline & RsMCrAg_T2 & $\begin{array}{l}\text { Mean value of agricultural credit operations in } \\
\text { municipality in } 2010\end{array}$ & $\mathrm{R} \$ \times 1000$ \\
\hline & RsCrAgPRD_T2 & $\begin{array}{l}\text { Relationship between total agricultural credit in } 2010 \\
\text { and mean deforestation up to } 2010 \text { from PRODES }\end{array}$ & $\mathrm{R} \$ \times 1000 / \mathrm{km}^{2}$ Deforest. \\
\hline & RsmCrAgPRD_T1T2 & $\begin{array}{l}\text { Relationship between total agricultural credit in } 2010 \\
\text { and mean deforestation between } 2000 \text { and } 2010 \\
\text { from PRODES }\end{array}$ & $\mathrm{R} \$ \times 1000 / \mathrm{km}^{2}$ Deforet \\
\hline \multirow[t]{2}{*}{$\begin{array}{l}\text { economics (Section 2.2.2) } \\
\text { Logística (Section 2.2.2.3.) }\end{array}$} & DEst & $\begin{array}{l}\text { Relationship between the total perimeter of roads and } \\
\text { the total municipal area }\end{array}$ & $\mathrm{km} / \mathrm{km}^{2}$ \\
\hline & DHdr & $\begin{array}{l}\text { Total perimeter of polygons and vectors for } \\
\text { hydrography of municipality/total area of municipality }\end{array}$ & $\mathrm{km} / \mathrm{km}^{2}$ \\
\hline \multirow{5}{*}{$\begin{array}{l}\text { territorial configuration } \\
\quad \text { (Section 2.2.3) } \\
\text { PRODES (Section 2.2.3.1.) }\end{array}$} & AMPRD_T1T2 & Mean area of PRODES polygons 2000-2010 & $\mathrm{km}^{2}$ \\
\hline & APPRD_T1T2 & Area/Perimeter of PRODES polygons 2000-2010 & - \\
\hline & DDesf_T2 & \% deforestation in municipality from PRODES for 2010 & $\%$ \\
\hline & DDesf_T1T2 & $\begin{array}{l}\text { Evolution of \% deforestation in municipality from } \\
\text { PRODES between } 2000 \text { and } 2010=\text { DdesfT2 - DdesfT1 }\end{array}$ & $\%$ \\
\hline & TxMDesf_T1T2 & $\begin{array}{l}\text { Mean rate of annual deforestation 2001-2010 } \\
\text { from PRODES. }\end{array}$ & $\%$ \\
\hline
\end{tabular}


Table A1. Cont.

\begin{tabular}{|c|c|c|c|}
\hline Dimension & Metric & Description & Unit \\
\hline \multirow{9}{*}{$\begin{array}{l}\text { territorial configuration } \\
\quad \text { (Section 2.2.3) } \\
\text { TerraClass (Section 2.2.3.2.) }\end{array}$} & AMPTC_T2 & Mean area of TerraClass 2010 polygons & $\mathrm{km}^{2}$ \\
\hline & APTC_T2 & Area/Perimeter of TerraClass 2010 polygons & - \\
\hline & DPTC_T2 & Density of TerraClass 2010 polygons & poligons $/ \mathrm{km}^{2}$ \\
\hline & DATCAA_T2 & Density of annual crop class from TerraClass 2010 & $\%$ \\
\hline & DATCMO_T2 & Density of mosaic occupation class from TerraClass 2010 & $\%$ \\
\hline & DATCPL_T2 & Density of clean pasture class from TerraClass 2010 & $\%$ \\
\hline & DATCPS_T2 & Density of dirty pasture class from TerraClass 2010 & $\%$ \\
\hline & DATCRP_T2 & Density of regerating pasture class from TerraClass 2010 & $\%$ \\
\hline & DATCVS_T2 & $\begin{array}{l}\text { Density of secondary vegetation class from } \\
\text { TerraClass } 2010\end{array}$ & $\%$ \\
\hline $\begin{array}{l}\text { territorial configuration } \\
\text { (Section 2.2.3) } \\
\text { Unidades Conservação } \\
\text { Ambiental (Section 2.2.3.3.) }\end{array}$ & DAUPA & $\%$ area of conservation units within municipality & $\%$ \\
\hline \multirow{10}{*}{$\begin{array}{l}\text { Social characteristics } \\
\quad \text { (Section 2.2.4) }\end{array}$} & IDHM_T2 & $\begin{array}{l}\text { Human development index (HDI) for 2010, composed of } \\
\text { three dimensions of human development: longevity, } \\
\text { education and income }\end{array}$ & Index ( 0 to 1$)$ \\
\hline & IDHM_T1aT2 & Evolution of municipal HDI between 2000-2010 & Index ( 0 to 1$)$ \\
\hline & DPobre_T2 & $\begin{array}{l}\% \text { of adults with an income equal to or below } \mathrm{R} \$ 14,000 \\
\text { per month in August } 2010\end{array}$ & $\begin{array}{l}\% \text { of municipal } \\
\text { population }\end{array}$ \\
\hline & EvDPobre_T1T2 & $\begin{array}{l}\text { Change in \% of people living under poverty between } \\
2000 \text { and } 2010\end{array}$ & $\begin{array}{l}\% \text { of municipal } \\
\text { population }\end{array}$ \\
\hline & DPAss & $\%$ municipal area occupied by settlement projects & $\%$ \\
\hline & PopR_T2 & Population of the rural zone (demographic census 2010) & Unit \\
\hline & EvPopR_T1T2 & Change in population in rural zone $2000-2010$ & Unit \\
\hline & PopRPRD_T2 & $\begin{array}{l}\text { Relationship between population of the rural zone and } \\
\text { mean deforestation to } 2010 \text { from PRODES }\end{array}$ & $\begin{array}{c}\text { inhabitants } / \mathrm{km}^{2} \\
\text { Deforest. }\end{array}$ \\
\hline & EvPopRPRD_T1T2 & $\begin{array}{l}\text { Change in relationship between population of the rural } \\
\text { zone and deforested from PRODES data, areas between } \\
2000 \text { and } 2010\end{array}$ & $\begin{array}{l}\text { inhabitants } / \mathrm{km}^{2} \\
\text { Deforest. }\end{array}$ \\
\hline & $\begin{array}{c}\text { EvPopRPRD_T1T2 } \\
(\%)\end{array}$ & $\begin{array}{l}\% \text { change in relationship between population of the } \\
\text { rural zone in } 2010 \text { and mean deforestation from } \\
\text { PRODES until } 2010\end{array}$ & $\%$ \\
\hline
\end{tabular}

Table A2 provides the proportional economic contribution of the five major crops' unit, and the classification of crop concentration in each municipality.

Table A2. Proportional economic contribution of the five major crops.

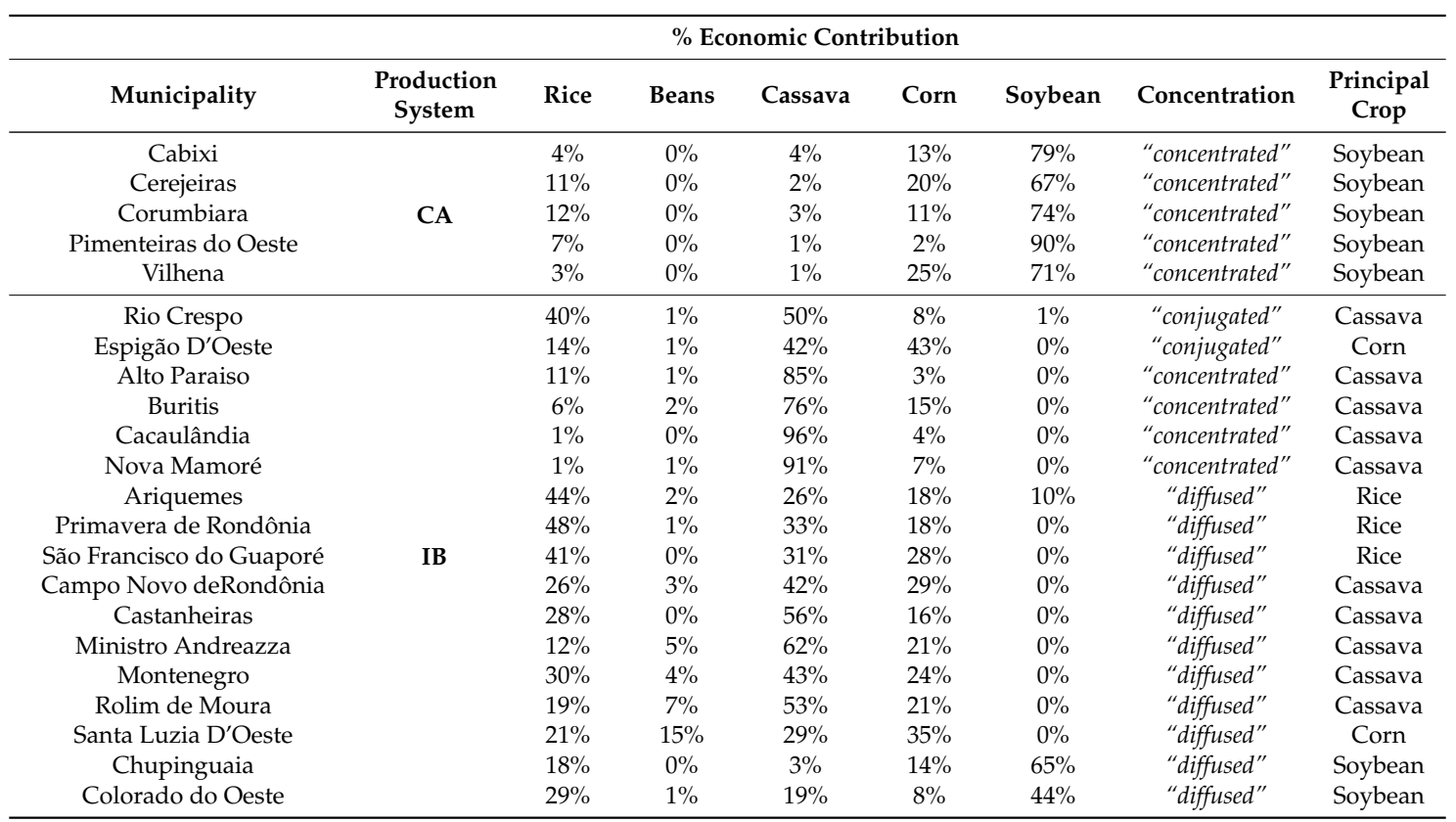


Table A2. Cont.

\begin{tabular}{|c|c|c|c|c|c|c|c|c|}
\hline \multirow[b]{2}{*}{ Municipality } & \multirow[b]{2}{*}{$\begin{array}{l}\text { Production } \\
\text { System }\end{array}$} & \multicolumn{6}{|c|}{$\%$ Economic Contribution } & \multirow[b]{2}{*}{$\begin{array}{c}\text { Principal } \\
\text { Crop }\end{array}$} \\
\hline & & Rice & Beans & Cassava & Corn & Soybean & Concentration & \\
\hline Presidente Medici & \multirow{13}{*}{ IBM } & $46 \%$ & $1 \%$ & $42 \%$ & $11 \%$ & $0 \%$ & "conjugated" & Rice \\
\hline Vale do Paraiso & & $6 \%$ & $3 \%$ & $24 \%$ & $67 \%$ & $0 \%$ & "conjugated" & Corn \\
\hline Ji-Paraná & & $2 \%$ & $1 \%$ & $83 \%$ & $14 \%$ & $0 \%$ & "concentrated" & Cassava \\
\hline Ouro Preto do Oeste & & $2 \%$ & $1 \%$ & $92 \%$ & $6 \%$ & $0 \%$ & "concentrated" & Cassava \\
\hline Alvorada D'Oeste & & $38 \%$ & $3 \%$ & $39 \%$ & $19 \%$ & $0 \%$ & "diffused" & Cassava \\
\hline Gov.Jorge Teixeira & & $8 \%$ & $24 \%$ & $45 \%$ & $23 \%$ & $0 \%$ & "diffused" & Cassava \\
\hline Jaru & & $11 \%$ & $12 \%$ & $61 \%$ & $16 \%$ & $0 \%$ & "diffused" & Cassava \\
\hline Nova União & & $12 \%$ & $13 \%$ & $56 \%$ & $18 \%$ & $0 \%$ & "diffused" & Cassava \\
\hline Novo Horizonte do Oeste & & $34 \%$ & $6 \%$ & $38 \%$ & $22 \%$ & $0 \%$ & "diffused" & Cassava \\
\hline Teixeirópolis & & $14 \%$ & $3 \%$ & $49 \%$ & $35 \%$ & $0 \%$ & "diffused" & Cassava \\
\hline Theobroma & & $20 \%$ & $3 \%$ & $55 \%$ & $22 \%$ & $0 \%$ & "diffused" & Cassava \\
\hline Vale do Anari & & $24 \%$ & $2 \%$ & $58 \%$ & $17 \%$ & $0 \%$ & "diffused" & Cassava \\
\hline Urupa & & $9 \%$ & $10 \%$ & $39 \%$ & $42 \%$ & $0 \%$ & "diffused" & Corn \\
\hline Cacoal & \multirow{11}{*}{ SIB } & $13 \%$ & $2 \%$ & $58 \%$ & $27 \%$ & $0 \%$ & "conjugated" & Cassava \\
\hline Costa Marques & & $24 \%$ & $2 \%$ & $66 \%$ & $8 \%$ & $0 \%$ & "conjugated" & Cassava \\
\hline Candeias do Jamari & & $4 \%$ & $0 \%$ & $95 \%$ & $1 \%$ & $0 \%$ & "concentrated" & Cassava \\
\hline Cujubim & & $14 \%$ & $5 \%$ & $77 \%$ & $5 \%$ & $0 \%$ & "concentrated" & Cassava \\
\hline Gujara-Mirim & & $1 \%$ & $0 \%$ & $93 \%$ & $5 \%$ & $0 \%$ & "concentrated" & Cassava \\
\hline Itapuã do Oeste & & $12 \%$ & $4 \%$ & $72 \%$ & $3 \%$ & $9 \%$ & "concentrated" & Cassava \\
\hline Pimenta Bueno & & $10 \%$ & $0 \%$ & $80 \%$ & $9 \%$ & $0 \%$ & "concentrated" & Cassava \\
\hline Seringueiras & & $15 \%$ & $1 \%$ & $74 \%$ & $9 \%$ & $0 \%$ & "concentrated" & Cassava \\
\hline Parecis & & $14 \%$ & $3 \%$ & $46 \%$ & $37 \%$ & $0 \%$ & "diffused" & Cassava \\
\hline Alta Floresta do Oeste & & $7 \%$ & $27 \%$ & $20 \%$ & $46 \%$ & $0 \%$ & "diffused" & Corn \\
\hline Alto Alegre do Parecis & & $10 \%$ & $24 \%$ & $26 \%$ & $40 \%$ & $0 \%$ & "diffused" & Corn \\
\hline São Miguel do Guaporé & \multirow{5}{*}{ SIBM } & $44 \%$ & $1 \%$ & $43 \%$ & $11 \%$ & $0 \%$ & "conjugated" & Rice \\
\hline Machadinho D'Oeste & & $10 \%$ & $3 \%$ & $76 \%$ & $12 \%$ & $0 \%$ & "concentrated" & Cassava \\
\hline São Felipe D'Oeste & & $41 \%$ & $13 \%$ & $8 \%$ & $38 \%$ & $0 \%$ & "diffused" & Rice \\
\hline Mirante da Serra & & $15 \%$ & $8 \%$ & $51 \%$ & $26 \%$ & $0 \%$ & "diffused" & Cassava \\
\hline Nova Brasilândia D'Oeste & & $18 \%$ & $5 \%$ & $62 \%$ & $16 \%$ & $0 \%$ & "diffused" & Cassava \\
\hline
\end{tabular}

\section{References}

1. Droulers, M. L'Amazonie Vers un Développement Durable, 1st ed.; Armand Colin: Paris, France, 2004.

2. Becker, B.K. Amazônia: Geopolítica na Virada do III Milênio; Editora Garamond: Rio de Janeiro, Brazil, 2004.

3. Becker, B.K. A Amazônia e a política ambiental brasileira. Geografia 2004, 6, 7-20.

4. Aguiar, A.P.D.; Câmara, G.; Escada, M.I.S. Spatial statistical analysis of land-use determinants in the Brazilian Amazonia: Exploring intra-regional heterogeneity. Ecol. Model. 2007, 209, 169-188. [CrossRef]

5. Richards, P.D.; Walker, R.T.; Arima, E.Y. Spatially complex land change: The Indirect effect of Brazil's agricultural sector on land use in Amazonia. Glob. Environ. Chang. 2014, 29, 1-9. [CrossRef] [PubMed]

6. Brondizio, E.S.; Moran, E.F. Human dimensions of climate change: The vulnerability of small farmers in the Amazon. Philos. Trans. R. Soc. Lond. B Biol. Sci. 2008, 363, 1803-1809. [CrossRef] [PubMed]

7. Browder, J.O.; Pedlowski, M.A.; Walker, R.; Wynne, R.H.; Summers, P.M.; Abad, A.; Becerra-Cordoba, N.; Mil-Homens, J. Revisiting theories of frontier expansion in the Brazilian amazon: A survey of the colonist farming population in Rondônia's post-frontier, 1992-2002. World Dev. 2008, 36, 1469-1492. [CrossRef]

8. De Assis Costal, F. Mercado e produção de terras na Amazônia: Avaliação referida a trajetórias tecnológicas. Bol. Mus. Para. Emilio Goeldi Ciênc. Hum. 2010, 5, 25-39.

9. Santos Junior, R.A.O.; Costa, F.D.A.; Aguiar, A.P.D.; de Toledo, P.M.; Vieira, I.C.G.; Câmara, G. Desmatamento, trajetórias tecnológicas e metas de contenção de emissões na Amazônia. Cienc. Cult. 2010, 62, 56-59.

10. De Mello, N.A.; Théry, H. L'État brésilien et l'environnement en Amazonie: Évolutions, contradictions et conflits. L'esp. Géogr. 2003, 32, 3-20.

11. Perz, S.G. The effects of household asset endowments on agricultural diversity among frontier colonists in the Amazon. Agrofor. Syst. 2005, 63, 263-279. [CrossRef]

12. Williams, K.J.H.; Schirmer, J. Understanding the relationship between social change and its impacts: The experience of rural land use change in south-eastern Australia. J. Rural Stud. 2012, 28, 538-548. [CrossRef]

13. Woods, M. Rural geography III: Rural futures and the future of rural geography. Prog. Hum. Geogr. 2012, 36, 125-134. [CrossRef] 
14. Li, Y.; Long, H.; Liu, Y. Spatio-temporal pattern of China's rural development: A rurality index perspective. J. Rural Stud. 2015, 38, 12-26. [CrossRef]

15. Anselin, L.; Sridharan, S.; Gholston, S. Using exploratory spatial data analysis to leverage social indicator databases: The discovery of interesting patterns. Soc. Indic. Res. 2007, 82, 287-309. [CrossRef]

16. Grigg, D. An introduction to Agricultural Geography, 2nd ed.; Routledge: London, UK, 2003.

17. Pacione, M. Progress in Agricultural Geography, 1st ed.; Routledge: New York, NY, USA, 2013.

18. Pecqueur, B. Esquisse d' une géographie économique territoriale. L'Espace. Géogr. 2014, 43, 198-214.

19. De Souza, E.C.; da Silva, G.J.C. Dinâmica espacial e formação de clusters significativos no setor agropecuário de Minas Gerais. Rev. Econ. Tecnol. 2012, 6, 107-116. [CrossRef]

20. Soler, L.S.; Verburg, P.H. Combining remote sensing and household level data for regional scale analysis of land cover change in the Brazilian Amazon. Reg. Environ. Chang. 2010, 10, 371-386. [CrossRef]

21. Espindola, G.M.; de Aguiar, A.P.D.; Pebesma, E.; Câmara, G.; Fonseca, L. Agricultural land use dynamics in the Brazilian Amazon based on remote sensing and census data. Appl. Geogr. 2012, 32, 240-252. [CrossRef]

22. Helfand, S.M.; Moreira, A.R.B.; Figueiredo, A.M.R. Explicando as diferenças de pobreza entre produtores agrícolas no Brasil: Simulações contrafactuais com o censo agropecuário 1995-1996. Rev. Econ. Sociol. Rural 2011, 49, 391-418. [CrossRef]

23. Southworth, J.; Munroe, D.; Nagendra, H. Land cover change and landscape fragmentation-Comparing the utility of continuous and discrete analyses for a western Honduras region. Agric. Ecosyst. Environ. 2004, 101, 185-205. [CrossRef]

24. Becker, B.K. Amazônia; Editora Ática: São Paulo, Brazil, 1990.

25. Théry, H. Routes et déboisement en Amazonie brésilienne, Rondônia 1974-1996. Mappemonde 1997, 97, 35-40.

26. Théry, H. Rondônia, Mutations d'un Territoire Fédéral en Amazonie Brésilienne; Université Panthéon-Sorbonne-Paris I: Paris, France, 1976.

27. Coy, M. Desenvolvimento regional na periferia amazônica: Organização do espaço, conflitos de interesses e programas de planejamento dentro de uma região de 'fronteira': O caso de Rondônia. In Fronteiras; Editora Universidade de Brasília: Brasilia, Brazil, 1988; pp. 167-194.

28. Théry, H. Situações da Amazônia no Brasil e no continente. Estud. Av. 2005, 19, 37-49. [CrossRef]

29. Xavier, A.D.S. Fronts Pionniers D'amazonie, Les Dinamiques Paysannes au Brésil, 1st ed.; CNRS Editions: Paris, France, 2006.

30. Fiori, M.F.; Fiori, L.E.; Nenevé, M. Colonização agrícola de Rondônia e (não) obrigatoriedade de desmatamento como garantia de posse sobre a propriedade rural. Novos Cad. Naea 2013, 16, 9-22. [CrossRef]

31. Instituto Nacional de Pesquisas Espaciais (INPE). Projeto PRODES-Monitoramento da Floresta Amazônica Brasileira por Satélite. 2015. Available online: http://www.dpi.inpe.br/prodesdigital/prodesmunicipal.php (accessed on 12 August 2015).

32. Da Coata Silva, R.G. A regionalização do agronegócio da soja em Rondônia. GEOUSP Espaç. Tempo (Online) 2014, 18, 298-312. [CrossRef]

33. De Almeida, C.A.; Coutinho, A.C.; Esquerdo, J.C.D.M.; Adami, M.; Venturieri, A.; Diniz, C.G.; Dessay, N.; Durieux, L.; Gomes, A.R. High spatial resolution land use and land cover mapping of the 1 Brazilian Legal Amazon in 2008 using Landsat-5/TM and MODIS data. Acta Amaz. 2016, 46, 291-302.

34. Instituto Brasileiro de Geografia e Estatística (IBGE). IBGE Cidades@. 2012. Available online: http://www. cidades.ibge.gov.br/xtras/home.php (accessed on 27 May 2012).

35. Tsunechiro, A.; Coelho, P.J.; Miura, M. Valor da produção agropecuária no Brasil, por unidade da federação em 2008. Rev. Inf. Econ. 2010, 40, 62-79.

36. Bacen. Anuário Estatístico do Crédito Rural. 2015. Available online: http://www.bcb.gov.br/?RELRURAL (accessed on 19 February 2015).

37. Sistema de Proteção da Amazônia (SIPAM). Malha Viária Geral do Estado de Rondônia. 2010. Available online: http:/ / www.metadados.inde.gov.br/geonetwork/srv/por/metadata.show?id=17627\&currTab= simple (accessed on 23 February 2015).

38. Naveh, Z. From biodiversity to ecodiversity: A landscape-ecology approach to conservation and restoration. Restor. Ecol. 1994, 2, 180-189. [CrossRef]

39. Wiens, J.A. What is landscape ecology, really? Landsc. Ecol. 1992, 7, 149-150. [CrossRef]

40. Cruz, C.; Madureira, H.; Marques, J. Análise espacial e estudo da fragmentação da Paisagem da Aboboreira. Rev. Geogr. Ordenam. Territ. 2013, 1, 57-82. [CrossRef] 
41. Carrão, H.M.S.; Caetano, M.; Neves, N. LANDIC-Cálculo de indicadores de paisagem em ambiente SIG. In Proceedings of Encontro de Utilizadores de Informação Geográfica-ESIG 2001, Oeiras, Portugal, 28-30 November 2001.

42. Pereira, J.L.G.; Batista, G.T.; Thalês, M.C.; Roberts, D.A.; Venturieri, A. Métricas da paisagem na caracterização da evolução da ocupação da Amazônia. Geografia 2001, 26, 59-90.

43. Johan, O.; Xavier, A.D.S.; Thibaud, D.; Valery, G.; Michel, G.; Antoine, L.; Rennes, U.; Moal, L.; Letg, U.M.R.; Cnrs, U.M.R.; et al. Utilisation de la télédétection et de donnés socio-économiques et écologiques pour compreendre l'impact des dynamiques de l'occupation des sols a Pacajà (Brésil). Rev. Fr. Photogramm. Télédétec. 2012, 198-199, 8-24.

44. Ziolkowski, D.; Turlej, K.; Bochenek, Z. Indicators of landscape diversity derived from remote sensing based land cover maps-Spatial and thematic aspects. Ecol. Quest. 2013, 17, 113-129. [CrossRef]

45. Gustafson, E. Quantifying landscape spatial pattern: What is the state of the art? Ecosystems 1998, 1, $143-156$. [CrossRef]

46. Ministério do Meio Ambiente. Cadastro Nacional de Unidade de Conservação. 2015. Available online: http:/ / www.mma.gov.br/areas-protegidas/cadastro-nacional-de-ucs/dados-georreferenciados (accessed on 18 May 2016).

47. Ceron, A.O.; de Oliveira Girardi, L.H. Geografia agrária e metodologia de pesquisa/agrarian geography and research metodology. CAMPO-TERRITÓRIO Rev. Geogr. Agrár. 2007, 2, 4-16.

48. Coelho, V.H.R.; Montenegro, S.M.G.L.; de Almeida, C.N.; de Lima, E.R.V.; Neto, A.R.; de Moura, G.S.S. Dinâmica do uso e ocupação do solo em uma bacia hidrográfica do semiárido brasileiro. R. Bras. Eng. Agríc. Ambient. 2014, 18, 64-72. [CrossRef]

49. Siedenberg, D.R. Indicadores de desenvolvimento socioeconomico. Desenvolv. Quest. 2003, 1, $45-71$.

50. Jannuzzi, P.D.M. Considerações sobre o uso, mau uso e abuso dos indicadores sociais na formulação e avaliação de políticas públicas municipais. Rev. Adm. Pública 2002, 36, 51-72.

51. Programa das Nações Unidas para o Desenvolvimento (PNUD); Instituto de Pesquisa Econômica Aplicada (IPEA); Fundação João Pinheiro. O Atlas do Desenvolvimento Humano no Brasil. 2015. Available online: http://www.atlasbrasil.org.br/2013/pt/o_atlas/o_atlas_/ (accessed on 19 February 2015).

52. Instituto Nacional de Colonização e Reforma Agrária (INCRA). Acervo Fundiário. Acervo Fundiário I3Geo; 2015. Available online: http://acervofundiario.incra.gov.br/i3geo/interface/incra.html? 63t9hg62kbk1eulgspj2ue5ui6 (accessed on 23 February 2015).

53. Ligêza, A. Logical foundations for rule-based systems. In Logical Foundations for Rule-Based Systems; Springer: Berlin/Heidelberg, Germany, 2006; pp. 191-198.

54. Geist, H.J.; Lambin, E.F. What Drives Tropical Deforestation?; LUCC Report Series, No 4; LUCC International Project Office: Louvain-la-Neuve, Belgium, 2001.

55. Margulis, S. Causes of Deforestation of the Brazilian Amazon; The World Bank: Washington, DC, USA, 2003.

56. Godar, J.; Gardner, T.A.; Tizado, E.J.; Pacheco, P. Actor-specific contributions to the deforestation slowdown in the Brazilian Amazon. Proc. Natl. Acad. Sci. USA 2014, 111, 15591-15596. [CrossRef] [PubMed]

57. Chomitz, K.M.; Thomas, T.S. Geographic Patterns of Land Use and Land Intensity in the Brazilian Amazon; World Bank Policy Research Working Paper No. 2687; The World Bank: New York, NY, USA, 2001.

58. Agência de Defesa Sanitária Agrosilvopastoril do Estado de Rondônia (IDARON). Levantamento de Dados Sobre a Produção de Leite em Rondônia. 2013. Available online: http://www.idaron.ro.gov.br/Multimidia/ downloads/docs/Producao_de_leite_em_Rondonia-divulgacao.pdf (accessed on 19 February 2015).

59. Soler, L.D.S.; Verburg, P.H.; Alves, D. Evolution of land use in the Brazilian Amazon: From frontier expansion to market chain dynamics. Land 2014, 3, 981-1014. [CrossRef]

60. Da Costa Silva, R.G. Amazônia globalizada: Da fronteira agrícola ao território do agronegócio-O exemplo de Rondônia. Confins 2015, 23. [CrossRef]

61. Hurtienne, T.P. Agricultura familiar e desenvolvimento rural sustentável na Amazônia. Novos Cad. Naea 2005, 8, 19-71. [CrossRef]

62. Becker, B.K. Reflexões sobre a Geopolítica e a logística da soja na Amazônia. In Dimensões Humanas da Biosfera-Atmosfera na Amazônia; Edusp: São Paulo, Brazil, 2007; p. 176.

63. Simon, M.F.; Garagorry, F.L. The expansion of agriculture in the Brazilian Amazon. Environ. Conserv. 2006, 32, 203-212. [CrossRef]

64. Euclides, V.P.B. Produção intensiva de carne bovina em pasto. Simp. Prod. Gado Corte 2001, 2, 55-82. 
65. Oliveira, R.L.; de Freitas Barbosa, M.A.A.; Ladeira, M.M.; da Silva, M.M.P.; Ziviani, A.C.; Bagaldo, A.R. Nutrição e manejo de bovinos de corte na fase de cria. Rev. Bras. Saúde Prod. Anim. 2006, 7, 57-86.

66. Instituto Brasileiro de Geografia e Estatísitca (IBGE). Série Relatórios Metodológicos. Produto Interno Bruto dos Municípios; IBGE: Rio de Janeiro, Brazil, 2004.

67. Bonelli, R. Impactos Econômicos e Sociais de Longo Prazo da Expansão Agropecuária no Brasil: Revolução Invisível e Inclusão Social; Instituto de Pesquisa Econômica Aplicada: Rio de Janeiro, Brazil, 2001.

68. De Janvry, A.; Sadoulet, E. Agricultural growth and poverty reduction: Additional evidence. World Bank Res. Obs. 2010, 25, 1-20. [CrossRef]

69. Le Tourneau, F. La distribution du peuplement en Amazonie brésilienne: L'apport des données par secteur de recensement contexte pionnier de l'Amazonie brésilienne, et nous proposions quelques La représentation de la population en Amazonie et ses enjeux. L'esp. Géogr. 2009, 38, 359-375.

70. Alves, D.S.; Escada, M.I.S.; Pereira, J.L.G.; de Albuquerque Linhares, C. Land use intensification and abandonment in Rondônia, Brazilian Amazônia. Int. J. Remote Sens. 2003, 24, 899-903. [CrossRef]

71. Soler, L.D.S.; Escada, M.I.S.; Verburg, P.H. Quantifying deforestation and secondary forest determinants for different spatial extents in an Amazonian colonization frontier (Rondonia). Appl. Geogr. 2009, 29, 182-193. [CrossRef]

72. Vale, P.M.; Andrade, D.C. Comer carne salva a Amazônia? A produtividade da pecuária em Rondônia e sua relação com o desmatamento. Estud. Soc. Agric. 2012, 20, 381-408.

73. Bermann, C. Impasses e controvérsias da hidreletricidade. Estud. Av. 2007, 21, 139-153. [CrossRef]

74. Tilt, B.; Braun, Y.; He, D. Social impacts of large dam projects: A comparison of international case studies and implications for best practice. J. Environ. Manag. 2009, 90, S249-S257. [CrossRef] [PubMed]

75. Browder, J.O.; Pedlowski, M.A.; Summers, P.M. Land use patterns in the Brazilian Amazon: Comparative farm-level evidence from Rondônia. Hum. Ecol. 2004, 32, 197-224. [CrossRef]

(C) 2016 by the authors; licensee MDPI, Basel, Switzerland. This article is an open access article distributed under the terms and conditions of the Creative Commons Attribution (CC-BY) license (http://creativecommons.org/licenses/by/4.0/). 